\title{
PREVELENCE OF HELICOBACTER SPECIES IN SOME EDIBLE AND NON EDIBLE CHICKEN OFFALS.
}

\author{
AMMAR M.A.M*; LUBNA M. EBRAHEEM ${ }^{*}$ and NAHED M. ABD ELAZIZ ${ }^{* *}$ \\ *Animal Health Research Institute, Assiut regional Lab. (AHRI), Egypt. \\ ** Food Hygiene Dept., Fac. Vet. Med. Sohag, South-Valley University \\ Email: mahmoud2014eg@yahoo.com
}

\section{ABSTRACT}

Received at: 29/12/2014

Accepted: 15/2/2015
The current surveillance study was carried out to determine the prevalence of Heticobacter spp. in a total 120 samples of fresh chicken offals (30 from each of liver, gizzard, heart and cecal contents). Also it was undertaken to determine the effect of different methods of cooking on the survival of isolated organism. The samples were collected from different poultry slaughter and evisceration shops in Assiut city. The biotyping showed that 25 (83.3\%), 28 (93.3\%), $9(30 \%)$ and 30 $(100 \%)$ of liver, gizzard, heart and cecal contents samples respectively were positive for Helicobacter spp., and upon using polymerase chain reaction (PCR) assay only $9(30 \%), 9(30 \%), 3(10 \%)$ and $12(40 \%)$ of these samples respectively were positive for the same organism. The positive samples of liver were found to be $3(10 \%)$ H.pylori and $6(20 \%)$ H.pullorum, while the positive samples of gizzard were found to be 3 (10\%) for each of H.pylori, H.pullorum and H.cinaedi, as to heart samples appears to only be contaminated with H.pullorum with a percentage of $10 \%$. Both H.pylori and H.canis could be isolated from 3 samples of cecal contents with a percentage of $10 \%$ for each, while H.pullorum could be isolated from 6 samples of cecal contents with a percentage of $20 \%$. The highest isolation rate of Helicobacters was achieved with cecal contents followed by liver and gizzard samples (both have an equal percent of contamination) then heart samples. H.pullorum has the highest incidence of isolation from both liver and cecal contents. Different methods of cooking were applied on the liver and gizzard samples, the obtained results pointed out that Helicabacter spp. could be isolated from $22.2 \%$ of grilled liver samples and from $11.1 \%$ of boiled gizzard samples, while could not be detected from gizzard samples which exposed to boiling then frying. These results indicated meat thermometer is necessary to safe cooking and internal temperature of $82{ }^{\circ} \mathrm{C}$ is enough to eliminate the Hilicobacter hazard. When visual colour and doneness indicators replaces the thermometer, the combined effect of boiling and frying is the efficient method of cooking for the destruction of Helicobacter organism. The public health significance of the isolated microorganisms as well as the preventive measures were discussed.

Keywords: Prevalence - Helicobacter species, PCR, chicken, offals, cooking, survival.

\section{INTRODUCTION}

Chickens are economic source of animal protein, consumed on a large scale in Egypt. Also their edible offals are highly demanded due to their high biological value, reasonable price, agreeable taste and ease of serving. Poultry meat production depends heavily on live bird markets because of marketing infrastructure insufficiencies, and consumer factors. Over 70 percent of the broilers are sold at small retail poultry shops. There are around 15,892 such retail shops in Egypt that sell either live or freshly slaughtered birds to the consumer. In addition, 4,305 small slaughtering and de-feathering points exist that sell freshly slaughtered and chilled birds and bird parts and most of these slaughtering points are within residential areas, (FAO, 2006).

In small-scale slaughtering facilities, birds are slaughtered and then scalded in hot water. The carcasses are then plucked and eviscerated, mostly by hand. At evisceration, the vent is opened, the internal organs are removed, and the gizzard, liver and heart may be harvested. These edible organs can be contaminated through spillage of the contents of the intestines. After evisceration, they are often washed, which may contribute to the dissemination of bacteria on and among them. (Arnold, 2007). 
The genus Helicobacter has expanded rapidly over the past decade and as more animal hosts are investigated, other new species will undoubtedly be discovered and the concept of Helicobacter will continue to expand. The genus Helicobacter nowadays includes at least 26 formally named species, with additional novel species in the process of being characterized (Whary and Fox, 2004).

Members of the genus Helicobacter are micro aerobic, spiral motile rod by flagella. The genus can roughly be divided into gastric and enterohepatic Helicobacter species. Both believed to be zoonotic pathogens (Josenhans et al., 2000).

All gastric Helicobacter species have strong urease activity, they manage to survive gastric acidity by expressing urease at a level higher than that for any other known microorganism (Sach et al., 2003), Helicobacter pylori is considered the most prevalent of this species. The bacteria may be transform into coccoid or spherical cell (Dewhirst et al., 2000), the actual phenomenon of this transformation has been investigated in H.pylori but not in other Helicobacter spp., several factors may influence the spiral to coccoid conversion of H.pylori, such as acid $\mathrm{pH}$, stress, oxygen, temperature and nutritional starvation.

In comparison to spiral forms, coccoid shapes of H.pylori have been demonstrated to possess damaged genomic DNA, less total amounts of DNA and RNA, a loss of membrane potential and considerably diminished levels of intracellular ATP, indicative of a metabolic state of cellular degeneration (Taneera et al., 2002).

It was found that H.pylori causes recurrent abdominal pain (Ozen et al., 2001), and growth retardation in children (Tasar et al., 2006). Also there was a close relation between eradication of H.pylori and prevention of gastric cancer (cheung et al., 2007).

In Egypt, the prevalence of H.pylori infection was reported to be $60 \%$ up to $86 \%$ of adult population (Frenck et al., 2006). This prevalence is considered a public health problem especially among low socioeconomic level population, probably due to the condition that favor the acquisition of infection such as precarious hygiene, crowded living conditions and absence or deficiency of sanitation (Graham et al., 1991).

The enterohepatic Helicobacter species have the characteristics of ultra structure and physiology in common with the gastric species.

To date, these enterohepatic agents have been identified in the intestinal tract and /or the liver of humans, mammals and birds (Inglis et al., 2006). The most common members of this group are H.pullorum,
H.cinaedi and H.canis. Various human cases of gastroenteritis, an increase of liver enzymes and gallbladder cancer were associated with H.pullorum infection (On et al., 2002), it has also been suggested that H.pullorum plays a role in Crohn's disease (Bohr et al., 2002).

H.cinaedi infection has been associated with septicaemia and meningitis in a neonate (Orlicek et al., 1993), also it play an important role in the pathophysiology of cholesterol gallstone development in mice and possibly in humans (Maurer et al., 2005). Recently, the DNA of H.cinaedi was detected in patients with pancreatic exocrine cancer (Nilsson et al., 2006). Both H.pullorum and H.canis are included in the causes of intestinal and hepatobiliary disease in birds (Solnick and Schauer, 2001).

To date various Gram-negative bacteria species including $H$. pulorum have been shown to produce CDT "Cytolethal distending toxin" (Taylor et al., 2003). This toxin blocks cell proliferation by activating DNA damage induced cell cycle checkpoint response (Li et al., 2002).

Helicobacter pylori was found to resist cold starvation for an extended period of time (Nilsson et al., 2002), also packaging in vacuum or air had little effect on survival of the organism, Stevenson et al. (2000). Heat is the most common, inexpensive, simplest and effective method used to destroy microorganisms, that it denatures the proteins and enzymes of the microorganisms. The meat thermometer is important tool to make sure all potentially harmful bacteria have been destroyed through proper cooking temperature. Hence, the United States Dept. of Agriculture (USDA) recommends consumers use a food thermometer to ensure the internal temperature of chicken breasts and whole chicken reaches $76.7^{\circ} \mathrm{C}$ and $82^{\circ} \mathrm{C}$, respectively (USDA, 2005).

It is worth mentioning that most of the Egyptian kitchens do not use a meat thermometer. They determine the doneness of meat most often by cutting the meat to evaluate changes in color and texture, or by other subjective techniques. In contrast, the food safety messages promoted to the U.S. consumer have changed from judging the doneness of cooked meat on the basis of its appearance to using a thermometer. This was in response to increasing evidence that the visual appearance of cooked meats does not necessarily indicate that a microbiologically safe cooking temperature has been achieved (Lyon et al., 2000). Also it is cleared that improper cooking is one of the main factors causing food borne illness (Panisello et al., 2000).

The aim of this study was to investigate the occurrence of Helicobacter spp. in chicken offals, 
collected from different poultry slaughter and evisceration shops in Assiut City employing combination of a modified conventional culture, Biochemical identification and a PCR assay. Also it was undertaken to determine the effect of different methods of cooking on the survival of isolated organism.

\section{MATERIALS and METHODS}

\section{Collection of samples:}

One hundred and twenty samples of fresh chicken (gizzard, heart, liver and cecum), 30 samples each were collected from different poultry slaughter and evisceration shops in Assiut city. Samples were collected carefully avoiding cross-contamination. The samples of each bird (liver, heart gizzard as well the cecum) were obtained immediately after slaughter. Each sample was packed separately into a sterile plastic bag using disposable gloves, tightly closed and placed in a cool box packed with ice during transportation to the laboratory and kept cool until microbiological examination within two hours.

\footnotetext{
Microbiological analysis for isolation of Helicobacter spp.:

Isolation procedure:

Isolation of Helicobacter species was adopted as described by Stevenson et al. (2000). From each of gizzard, heart and liver, approximately $2 \mathrm{~g}$ sample was aseptically weighed into separate sterile $9 \mathrm{~mL}$ Helicobacter Special Peptone Broth (HPSPB) tubes supplemented with (Helicobacter antibiotic supplement (SIGMA) and 5\% calf serum). The tubes containing the samples were homogenized using a vortex then incubated at $37^{\circ} \mathrm{C}$ for 48 hours under microaerophilic condition using an anaerobic jar and gas generating kits (Oxoid CN 35).
}

From each enrichment culture, a loopful was streaked onto Columbia Blood Agar (CBA) plate supplemented with (Helicobacter antibiotic supplement and 5\% dfibrinated sheep blood) and incubated at $37^{\circ} \mathrm{C}$ for 4 days under microaerophilic condition.

The cecal contents was inoculated by passive filtration method as recommended by Steele and McDermott (1984). For passive filtration, 5 grams of cecal contents were mixed with sterile phosphate buffer saline (approximately 1/10 dilution) to produce a suspension. Approximately $100 \mu \mathrm{l}$ of this suspension was then carefully layered onto a $0.65 \mu \mathrm{m}$ filter, which was previously placed on top of Columbia blood agar plate with supplements. The bacteria are allowed to migrate through the filter for 45 minutes at $37^{\circ} \mathrm{C}$. The filter was then removed, the fluid that had passed through the filter was spread with a sterile glass, and the plates were incubated at $37^{\circ} \mathrm{C}$ for 4 days under microaerophilic condition.

Suspected colonies of Helicobacter spp. (grayish white) were checked by Gram's stain. Gram negative, gently curved, slender rod bacteria were subjected to oxidase, catalase and microscopic examination of wet mounts under phase contrast. Colonies giving reactions typical for Helicobacter spp. were purified by subculturing on blood agar plates. Helicobacter spp. were confirmed using the protocol recommended by Zenner (1999) and Murray et al. (2003). As phenotypic and biochemical tests may result in misidentification thus confirmation of the suspected isolates was carried out using PCR.

\section{Helicobacter genus-specific polymerase chain reaction (PCR): \\ Application of PCR for identification of $16 \mathrm{~S}$ rRNA gene of Helicobacter species was performed essentially by using Primers (Pharmacia Biotech) as shown in the following table:}

Table 1: Primer sequences for Helicobacter spp. polymerase chain reaction

\begin{tabular}{llcl}
\hline Target gene & Oligonucleotide sequence $\left(\mathbf{5}^{\prime} \rightarrow \mathbf{3}^{\prime}\right)$ & $\begin{array}{c}\text { Amplicon } \\
\text { length (bp) }\end{array}$ & Reference \\
\hline 16S rRNA (F) & $5^{\prime}$-CTATGACGGGTATCCGGC-3' & 375 & Moyaert et al. (2008) \\
\cline { 1 - 2 } & & & \\
\hline
\end{tabular}

DNA preparation from bacterial culture: (Riley et al., 1996)

Helicobacteria were harvested from their specific agar plates by suspending one or two colonies in 20 $\mathrm{ml}$ phosphate buffered saline $(\mathrm{pH}$ 7.4) and the suspension was then heated at $100^{\circ} \mathrm{C}$ for 20 minutes.
From this suspension, a $5 \mu \mathrm{l}$ aliquot was directly used as a template for PCR amplification.

DNA amplification: (Germani et al., 1997):

The amplification was performed on a Thermal Cycler (Master cycler, Eppendorf, Hamburg, 
Germany) using $25 \mu \mathrm{l}$ of PCR mixture containing $3 \mu \mathrm{l}$ of boiled cell lysate, $250 \mu \mathrm{M}$ of each desoxynucleotide triphosphate, 1.5 U of Taq DNA polymerase (Biotools, Madrid, Spain), buffer (20 mM Tris- $\mathrm{HCl} \mathrm{pH} \mathrm{8.4,} 50 \mathrm{mM} \mathrm{KCl}$ and $3 \mathrm{mM} \mathrm{MgCl}$, Biotools), $1 \mu \mathrm{M}$ of the primers mecA-R, mecA-F; 0.8 $\mu \mathrm{M}$ of icaA-R, icaA-F and $0.8 \mu \mathrm{M}$ of icaD-R, icaD-F. Amplification conditions included 35 cycles consisting of denaturation $\left(94^{\circ} \mathrm{C}\right.$ for 2 seconds), primer annealing $\left(53^{\circ} \mathrm{C}\right.$ for 2 seconds) followed by for final extension $\left(72^{\circ} \mathrm{C}\right.$ for 30 seconds). Amplified products were analyzed by $2 \%$ of agarose gel electrophoresis stained with ethidium bromide and visualized and captured on UV transilluminator.

\section{Effect of cooking on the survival of Helicobacter spp:}

Preparation of samples:

The same samples of gizzard and liver used in the survey study were used in the cooking experiment. Cooking was done as rapid as possible after sampling as raw.

Cooking methods: Pourkhalili et al. (2013)

Liver samples were subjected to grilling using burning stove where the sample were placed at $10 \mathrm{~cm}$ above the flame for $10 \mathrm{~min}$ with turning by 2 minutes interval (developing internal pink color ). The internal temperatures just after grilling was $70^{\circ} \mathrm{C}$ as determined using digital thermometer (thermometer ST-131 waterproof digital). Grilled samples were bacteriologically examined when their temperatures reached $15^{\circ} \mathrm{C}$.

The gizzard samples were subjected to two methods of cooking, the 1st was boiling while the 2nd was boiling then frying. Boiling of gizzard samples was performed at approximately $97^{\circ} \mathrm{C}$ (water temperature) for $30 \mathrm{~min}$ (developing internal grayish brown color and the juices run clear) in stainless steel pan. The internal temperature immediately after cooking was $78^{\circ} \mathrm{C}$. The boiled samples were bacteriologically examined when their temperatures reached $15^{\circ} \mathrm{C}$ then immediately fried in a pan using sunflower oil for 20 minutes (developing golden colour). The internal temperature immediately after frying was $85^{\circ} \mathrm{C}$. Also the fried samples were bacteriologically examined when their temperatures reached $15{ }^{\circ} \mathrm{C}$. The bacteriological examination of both control and cooked samples was carried out as described before according to Zenner (1999), Stevenson et al. (2000) and (Murray et al., 2003).

\section{RESULTS}

Table 2: Prevalence of Helicobacter spp. in edible and non edible offals.

\begin{tabular}{|c|c|c|c|c|c|c|c|c|c|c|c|c|c|}
\hline \multirow{3}{*}{$\begin{array}{l}\text { Type of } \\
\text { sample }\end{array}$} & \multirow{3}{*}{$\begin{array}{c}\text { No. } \\
\text { examined } \\
\text { samples }\end{array}$} & \multicolumn{4}{|c|}{ Helicobacter spp. } & \multicolumn{8}{|c|}{ Classified Helicobacter spp. } \\
\hline & & \multicolumn{2}{|c|}{ Biochemical } & \multicolumn{2}{|c|}{ PCR } & \multicolumn{2}{|c|}{ H.pylori } & \multicolumn{2}{|c|}{ H.pullorum } & \multicolumn{2}{|c|}{ H.canis } & \multicolumn{2}{|c|}{ H.cinaedi } \\
\hline & & $\begin{array}{c}\text { No. of } \\
+ \text { ve }\end{array}$ & $\%$ & $\begin{array}{c}\text { No. of } \\
+ \text { ve }\end{array}$ & $\%$ & $\begin{array}{c}\text { No. of } \\
+ \text { ve }\end{array}$ & $\%$ & $\begin{array}{c}\text { No. of } \\
\text { +ve }\end{array}$ & $\%$ & $\begin{array}{c}\text { No. of } \\
+ \text { ve }\end{array}$ & $\%$ & $\begin{array}{c}\text { No. of } \\
+ \text { ve }\end{array}$ & $\%$ \\
\hline Liver & 30 & 25 & 83.3 & 9 & 30 & 3 & 10 & 6 & 20 & 0 & 0 & 0 & 0 \\
\hline Gizzard & 30 & 28 & 93.3 & 9 & 30 & 3 & 10 & 3 & 10 & 0 & 0 & 3 & 10 \\
\hline Heart & 30 & 9 & 30 & 3 & 10 & 0 & 0 & 3 & 10 & 0 & 0 & 0 & 0 \\
\hline cecum & 30 & 30 & 100 & 12 & 40 & 3 & 10 & 6 & 20 & 3 & 10 & 0 & 0 \\
\hline Total & 120 & 92 & 76.7 & 33 & 27.5 & 9 & 7.5 & 18 & 15 & 3 & 2.5 & 3 & 2.5 \\
\hline
\end{tabular}


Table 3: Effect of grilling on the survival of Helicobacter spp. in liver samples.

\begin{tabular}{cccc}
\hline \multirow{2}{*}{ Type of samples } & No. of examined samples & +ve samples of Helicobacter spp. \\
\cline { 3 - 4 } & & No & $\%$ \\
\hline Raw liver (control) & 9 & 9 & 100 \\
\hline Grilled liver & 9 & 2 & 22.2 \\
\hline
\end{tabular}

Table 4: Effect of boiling and both boiling and frying on the survival of Helicobacter spp. in gizzard samples

\begin{tabular}{cccc}
\hline & No. of examined samples & \multicolumn{2}{c}{+ +ve samples of Helicobacter spp. } \\
\cline { 3 - 4 } Type of samples & 9 & No & $\%$ \\
\hline Raw gizzard (control) & 9 & 9 & 100 \\
\hline Boiled gizzard & 9 & 1 & 11.1 \\
\hline Boiled and fried gizzard & 9 & 0 \\
\hline
\end{tabular}

$\begin{array}{llllllllllllll}M & 1 & 2 & 3 & 4 & 5 & 6 & 7 & 8 & 9 & 10 & 11 & 12 & 13\end{array}$

375 bp

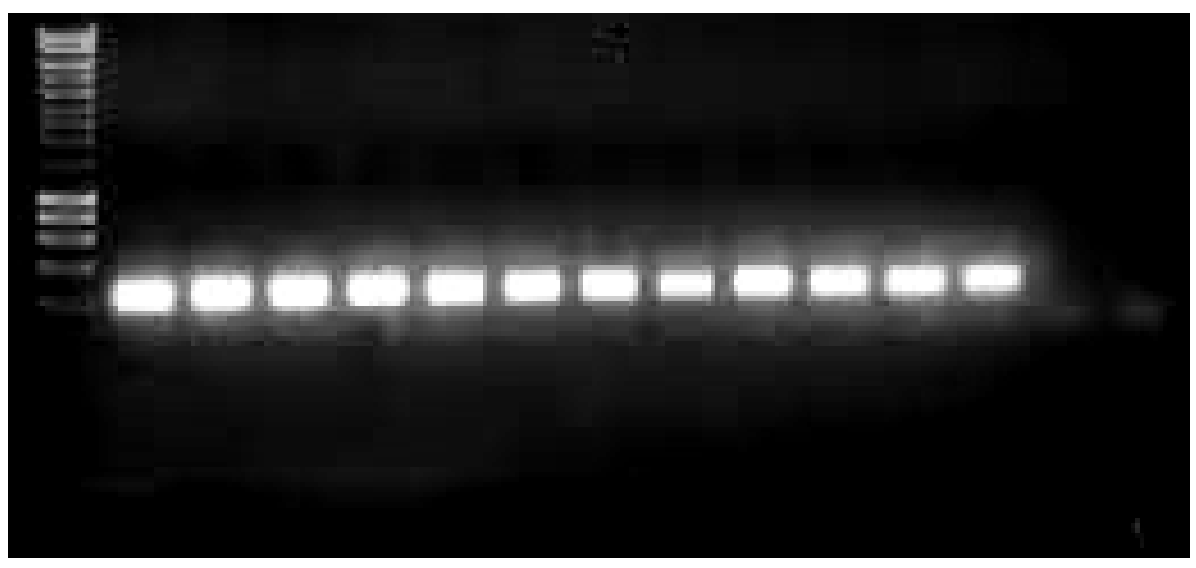

Fig. 1: Agarose gel electrophoresis of PCR amplification products using genus specific primer for detection of Helicobacter species.

Lane M: 100 bp ladder as molecular DNA marker.

Lane 1: Control positive for Helicobacter species.

Lane 13: Control negative for Helicobacter species.

Lane 2 to Lane 12: Positive strains as Helicobacters.

\section{DISCUSSION}

Helicobacter is a significant problem within the developing world, and its importance is unlikely to diminish in the foreseeable future, which abound the opportunities of future research. In this study, samples of cecal contents of chicken were investigated as a source of contamination with Helicobacter. The extent of contamination of gizzards, livers and hearts with Helicobacter was also studied.

Helicobacter species are fastidious bacterial pathogens that are difficult to isolate, therefore using PCR method is more helpful for detection of these fastidious bacteria. 
Table (1) shows that thirty samples from each of liver, gizzard, heart and cecal contents of chicken were examined for the presence of Helicobacters.

Biochemical tests showed that 25 (83.3\%), 28 (93.3\%), 9(30\%) and $30(100 \%)$ of these samples respectively were positive for this organism, and upon using PCR assay only 9 (30\%), 9(30\%), 3(10\%) and $12(40 \%)$ of these samples, respectively were positive for the same organism.

The positive samples of liver were found to be 3(10\%) H.pylori and 6 (20\%) H.pullorum, while the positive samples of gizzard were found to be 3 (10\%) for each of H.pylori, H.pullorum and H.cinaedi. Also the same table shows that heart samples only contaminated with H.pullorum with a percentage of 10\%. Both H.pylori and H.canis could be isolated from 3 samples of cecal contents with a percentage of $10 \%$ for each, while H.pullorum could be isolated from 6 samples of cecal contents with a percentage of $20 \%$.

The highest isolation rate of Helicobacters was achieved with cecal contents followed by liver and gizzard samples (both have an equal percent of contamination) then heart samples. H.pullorum has the highest incidence of isolation from both liver and cecal contents samples.

Regarding the highest isolation rate from cecal contents, (celeen et al., 2006) assumed that the lower segments of the intestinal tract are the predominant colonization sites for H.pullorum in broiler chickens. H.pullorum may gain access to the liver by retrograde movement from the duodenum. Alternatively, it may transfer from the gut lumen to the portal circulation.

A number of factors have been reported in the colonization of the organism in chicken, among these risk factors are inadequately cleaned and disinfected houses and facilities, presence of pests and pets, contaminated water supplies as well as boots and clothes of farm worker (Newell and Fearnley, 2003).

Several reports were published about the incidence and prevalence of H.pullorum from cecal samples. Zanoni et al. (2007), Mohamed, (2011), Beren, (2013) and Jamshidi et al. (2014), found an incidence rate of $100 \%, 50 \% 32.29 \%$ and $41 \%$ respectively upon sampling the caecal contents of chicken, which are higher than that obtained in our result.

Regarding to isolation rate of H.pullorum in liver samples (Ceelen et al., 2006; Liesbeth et al., 2006; Moemen et al., 2010; Mohamed, 2011 and Hassan et al., 2014), found this rate to be $4.6 \%, 4.6 \%, 47 \%$, $14 \%$ and $47 \%$ respectively, the present study declared higher incidence than that recorded by (Ceelen et al., 2006), (liesbeth et al., 2006) and (Mohamed, 2011), on the other hand (Moemen et al., 2010) and (Hassan et al., 2014) recorded higher results than that obtained in our study.

Also (Mohamed, 2011) could detect H.pullorum in $6 \%$ of gizzard samples, he reported that H.pylori was found in $16 \%, 4 \%$ and $6 \%$, of intestinal contents, liver and gizzard, respectively. He also announced that H.canis could be isolated from $2 \%$ of both intestinal contents and gizzared samples, while H.cinaedi could be isolated only from $6 \%$ of intestinal contents.

Cooking is the process of producing safe and edible foods. It is clear that cooking has been around for a long time and continues today to play a fundamental role in daily life across the globe. Cooking was first used for preservation but it has evolved and now it is a form of entertainment and creativity for many people. The fundamental types of cooking are boiling, grilling and frying. Boiling is a method of cooking in which food cooked in boiling water for a certain time according to the type of food, grilling is cooking of food using a direct dry heat, while frying is the cooking of food in oil or fat. Common types of food that are grilled and fried include fish, meat and chicken (EUFIC, 2010).

To explore the efficiency of Egyptian cooking methods in elimination of Helicobacter contaminating chicken offals, gizzard and liver samples were cooked in ways similar to what is done at home kitchen. From the tabulated data in table (3), the percentage of Helicobacter spp. in grilled liver samples was $22.2 \%$, and as presented in table (4) the same organism was recovered from $11.1 \%$ of boiled gizzard samples and could not be detected from gizzard samples which exposed to boiling then frying.

The consumer opinion that judging offals doneness using the appearance, resulted in elimination of Helicobacter only by the combination effect of both boiling and frying. The internal temperature of the treated samples $\left(82{ }^{\circ} \mathrm{C}\right)$ exceeded the safety cooking temperature $\left(76.4{ }^{\circ} \mathrm{C}\right)$ recommended by (USDA, 2005).

The survival of Helicobacter spp. in some cooked samples may be attributed to the fact that, consumers considered the appearance of doneness signs is the end point of cooking (the minim cooking temperature achieved but not continue for proper time). In this respect Whyte et al. (2006) mentioned that chicken liver must cooked to internal temperature in excess of $70{ }^{\circ} \mathrm{C}$ and held at that temperature for 2 to 3 minutes.

In conclusion Helicobater organism was detected in chicken offals which may contaminate the carcasses, that all present a potential hazard for public health. Therefore, it is essential to identify the risk factors for 
the presence of Helicobacters for human health, and proper cooking for both chicken carcasses and their offals. Meat thermometer is necessary to safe cooking and internal temperature of $82{ }^{\circ} \mathrm{C}$ is enough to eliminate the Hilicobacter hazard. When visual colour and doneness indicators replace the thermometer, our results indicated that the combined effect of boiling and frying is the best method of cooking for the destruction of Helicobacter organism.

\section{REFERENCES}

Arnold, J.W. (2007): Bacterial contamination on rubber picker fingers before, during, and after processing. Poult. Sci., 86(12): 2671-2675.

Beren, B.K. (2013): Investigation of Helicobacter Pullorum occurrence in chicken in the Marmara Region of Turkey. J. Fac. Vet. Med. Istanbul Univ. 39 (1): 63-66.

Bohr, U.R.M.; Primus, A.; Zagoura, A.; Glasbrenner, B.; Wex, T. and Malfertheiner, P. (2002): A group-specific PCR assay for the detection of Helicobacteraceae in human gut. Helicobacter 7: 378-383.

Ceelen, LM.; Decostere, A.; Van den Bulck, K.; On, SL.; Baele, M.; Ducatelle, $R$. and Haesebrouck, F. (2006): Helicobacter pullorum in chickens, Belgium. Emerg. Infect. Dis. 12: 263-267.

Cheung, T.K.; Xia, H.H. and Wong, B.C. (2007): Helicobacter pylori eradication for gastric cancer prevention. J. Gastroenterology 42: $10-15$.

Dewhirst, F.E.; Fox, J.G. and On, S.L.W. (2000): Recommended minimal standards for describing new species of the genus Helicobacter. International Journal of Systemic and Evolutionary Microbiology 50: 2231-2237.

EUFIC "European Union Food Information Council" (2010): The why, how and consequences of cooking our food. Cooking review -part 1: introduction.

FAO "Food and Agriculture Organization" (2006): The Structure and Importance of the Commercial and Village Based Poultry Systems in Egypt, FAO technical papers.

Frenck, R.W.; Fathy, H.M.; Sherif, M.; Mohran, Z.; El-Mohammedy, H. and Francis, W. (2006): Sensitivity and specificity of various tests for the diagnosis of Helicobacter pylori in Egyptian children. Pediatrics 118: 1195-1202.

Germani, Y.; Dauga, C.; Duval, P.; Huerre, M.; Levy, M.; Pialoux, G.; Sansonetti, P. and Grimont, P. (1997): Strategy for the detection of Helicobacter species by amplification of 16S rRNA genes and identification of $\mathrm{H}$. felis in a human gastric biopsy. Res. Microbiol., 148: $315-326$.
Graham, D.; Malaty, H.; Evans, D.; Evans, Jr.D.; Klein, P. and Adam, E. (1991): Epidemiology of Helicobacter pylori in an asymptomatic population in the United States. Effect of age, race, and socioeconomic status. Gastroenterology 100: 1459-1501.

Hassan, A.K.; Shahata, M.A.; Refaie, E.M. and Ibrahinm, R.S. (2014): Detection and identification of Helicobacter pullorum in poultry species in Upper Egypt. Adcanced Vet. Research Vol.4, Issue1, 42-48.

Inglis, D.G.; McConville, M. and de Jong, A. (2006): Atypical Helicobacter Canadensis strains associated with swine. Applied and Environmental Microbiology 72: 4464-4471.

Jamshidi, A.; Bassami, M.R.; Salami, H. and Mohammadi, S. (2014): Isolation and identification of Helicobacter Pullorum from caecal content of broiler chickens in Mashhad, Iran, Iranian Journal of Veterinary Research. 15 (2): 179-182.

Josenhans, C; Eaton, K.A; Thavenot, T. and Suerbaum, S. (2000): Switching of flagellar motility in Helicobacter pylori by reversible length variation of a short homopolymeric sequence repeat in flip, a gene encoding a basal body protein, infect. Immun. 68 (8): 4598-4603.

Li, L.; Sharipo, A.; Chaves-Olarte, E.; Masucci, M.G.; Levitsky, V.; Thelestam, M. and Frisan, T. (2002): The Haemophilus ducreyi cytolethal distending toxin activates sensors of DNA damage and repair complexes in proliferating and non-proliferating cells. Cellular Microbiology 4: 87-99.

Liesbeth, C.; Annemie, D.; Kathleen, V.; Stephen, L.W.; Margo, B.; Richard, D. and Freddy, $H$. (2006): Helicobacter pullorum in chickens, Belgium. Emerging infectious Diseases. www.cdc.gov/eid. vol.12 (2): 263-267.

Lyon, B.G.; Berry, B.; Soderberg, D. and Clinch, N. (2000): Visual colour and doneness indicators and the incidence of premature brown color in beef patties cooked to four end point temperatures. J. Food Prot. 63: 1389-98.

Maurer, K.J.; Ihrig, M.M.; Rogers, A.B.; Bouchard, G.; Leonard, M.R.; Carey, M.C. and Fox, J.G. (2005): Identification of cholelithogenic enterohepatic Helicobacter species and their role in murine cholesterol gallstone formation. Gastroentrology 128: 1023-1033.

Moemen, A.M.; Ragab, SI.; Moustafa, AS. and ElRefaie, MEIR (2010): Helicobacter pullourm among poultry in Assiut -Egypt: genetic characterization, virulence and MIC. Int. J. Poult. Sci. 9: 521-526.

Mohamed, N. (2011): Monitoring of Helicobacter spp., in poultry processing plant with special reference to H.pylori. Thesis submitted to faculty of veterinary medicine, Moshtohor, 
Benha University for the degree of M.V.Sc. (Meat hygiene), food control Department PP: 127-239.

Moyaert, H.; Pasman, F.; Ducatelle, R.; Haesebrouk, F. and Baele, M. (2008): Evaluation of $16 \mathrm{~S}$ rRNA gene-based PCR assays for genus-level identification of Helicobacter species. J. Clin. Microbiol., 46(5): 1867-1869.

Murray, P.; Baron, E.; Jorgensen, J.; Pfaller, M. and Yolken, R. (2003): Manual of clinical microbiology. 8th Ed., ASM Press, 1752 Nst NW, 20036-2904, Washington, D.C., USA.

Newell, DG. and Fearnley, C. (2003): Sources of campylobacter colonization in broiler chickens. Appl. Environ. Microbiol. 69: 4343-4351.

Nilsson, H.; Blom, J.; AlSoud, W.; Ljungh, A.; Andersen, L.P. and Wadström, T. (2002): Effect of Cold Starvation, Acid Stress, and Nutrients on Metabolic Activity of Helicobacter pylori. Appl Environ Microbiol. 68(1): 11-19.

Nilsson, H.O.; Stenram, U.; Ihse, I. and Wadstrom, T. (2006): Helicobacter species ribosomal DNA in the pancreas, stomach and duodenum of pancreatic cancer patients. World Journal of Gastroentrology 12: 3038-3043.

On, S.L.W.; Hynest, S. and Wadstom, T. (2002): Extragastric Helicobacter species. Helicobacter 7 suppl. 1: 63-67.

Orlicek, S.L.; Welch, D.F. and Kuhls, T.L. (1993): Septicemia and meninigitis caused by Helicobacter cinaedi in a neonate. Journal of Clinical Microbiology 31: 569-571.

Ozen, H.; Dinler, G.; Akyon, Y.; Kocak, N.; Yuce, A. and Gurakan, F. (2001): Helicobacter pylori infection and recurrent abdominal pain in Turkish children. Helicobacter 6: 234-237.

Panisello, P.J.; Rooney, R.; Quantick, P.C. and Stan well-smith, R. (2000): Application of food borne disease outbreak data in the development and maintenance of HACCP system. International Journal of food Microbiology. 59 (3): 221-234.

Pourkhalili, A.; Mirlohi, M. and Rahimi, E. (2013): Heme Iron Content in Lamb Meat Is Differentially Altered upon Boiling, Grilling, or Frying as Assessed by Four Distinct Analytical Methods. Scientific World Journal Vol. 2013: 1-5.

Riley, L.; Franklin, C.; Hook, R. and Besch-Williford, C. (1996): Identification of murine helicobacters by PCR and restriction enzyme analysis. J. Clin. Microbiol., 34: 942-946.

Sach, G.; Week, D.L.; Melchers, K. and Scott, D.R. (2003): The gastric biology of Helicobacter pylori. Annual Reviews of physiology 65: 349-369.

Solnick, J.V. and Schauer, D.B. (2001): Emergence of Diverse Helicobacter species in the pathogenesis of gastric and enterohepatic disease. Clinical Microbiology Reviews 14: 59-97.

Steele, T.W. and Mcdermott, S.N. (1984): The use of membrane filters applied directly to the surface of agar plates for the isolation of Campylobacter jejuni from feces. Pathology, 16, 263-265.

Stevenson, T.H.; Bauer, N.; Lucia, L.M. and Acuff, G.R. (2000): Attempts to isolate Helicobacter from cattle and survival of Helicobacter pylori in beef products. J. Food Prot. 63(2):174-178.

Taneera, J.; Moran, A.P.; Hynes, S.O; Nilsson, H.O.; Al-soud, W. and Wadstrom, T. (2002): Influence of activated charcoal porcine gastric mucin and beta-cyclodextrin on the morphology and growth of intestinal and gastric Helicobacter spp. Microbiology 148: 677-684.

Tasar, A.; Kibrisli, E. and Dallar, Y. (2006): Prevalence of Helicobacter pylori in children with constitution heigh retardation. Tur. J. Gastroneterology 17: 7-12.

Taylor, N.C; Ge, Z.; Shen, Z.; Dewhirst, F.E. and Fox, J.G. (2003): Cytolethal distending toxin: a potential virulence factor for Helicobacter cinaedi. Journal of infectious Disease 188: 1892-1897.

USDA "United States Department of Agriculture" (2005): Food safety education: is it done yet? Washington, D.C.: Food Safety and Inspection Service, United States Department of Agriculture. Available from: http://www. fsis. usda.gov/IsItDoneYet/index.asp.

Whary, M.T. and Fox, J.G. (2004): Natural and experimental Helicobacter infection. Comparative Medicine (54): 128-158.

Whyte, R.; Hudson, J. and Graham, C. (2006): Campylobacter in chicken liver and their destruction by pan-frying. Lett Appl Microbiol; 43(6): 591-595.

Zanoni, R.G.; Rossi, M.; Giacomucci, D.; Sanguinetti, V. and Manfreda, G. (2007): Occurrence and antibiotic susceptibility of Helicobacter pullorum from broiler chickens and commercial laying hens in Italy. International Journal of Food Microbiology 116: $168-173$.

Zenner, L. (1999): Pathology, diagnosis and epidemiology of the rodent Helicobacter infection. Comparative Immunol. and Infect., 48: 507-511. 


\section{مدي تواجد ميكروبات الهليكوباكتر في بعض احشاء الدجاج الصالحة والغير صالحة للإستهلاك}

\section{محمود عمار محمد عمار ، لبني محمد ابراهيم ، ناهل محمود عبل العزيز}

Email: mahmoud2014eg@yahoo.com

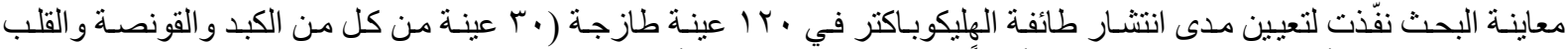

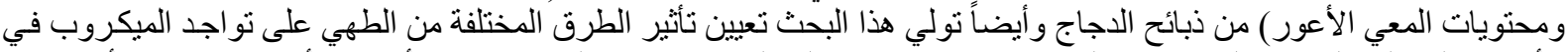

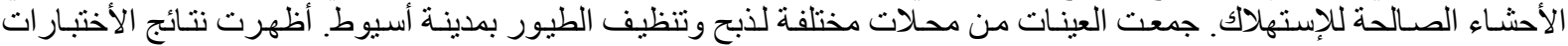

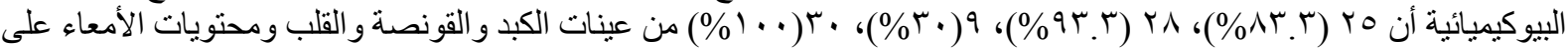

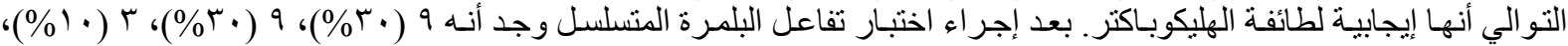

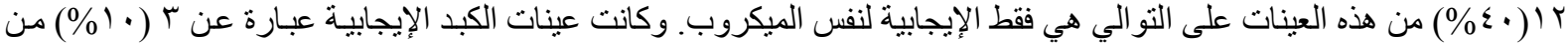

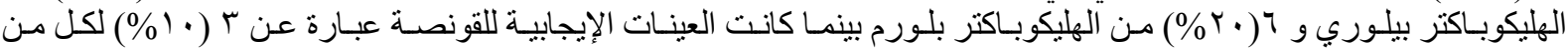

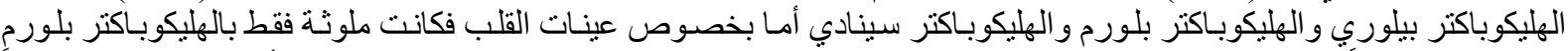

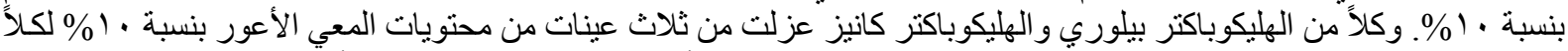

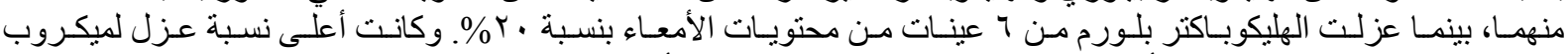

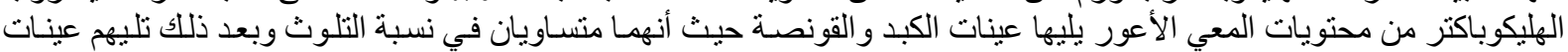

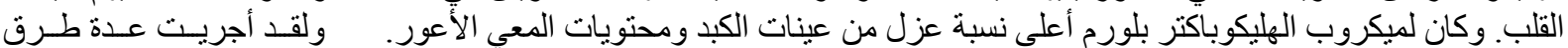

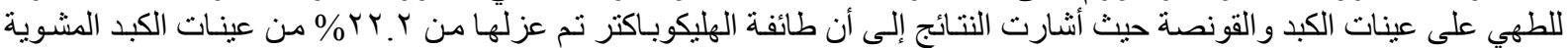

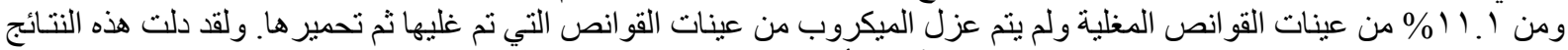

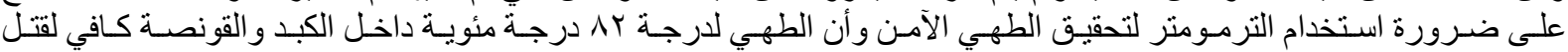

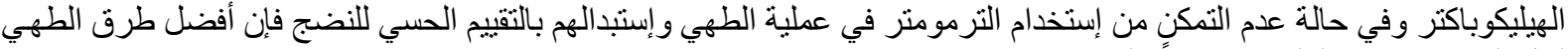
لقتل الميكروب هي الغلي مصحوباً بالتحمير. 